\title{
Penanganan Dekadensi Moral melalui Penerapan Karakter Cinta Damai dan Nasionalisme
}

\author{
Vera Yuli Erviana* \\ Pendidikan Guru Sekolah Dasar, Fakultas Keguruan dan Ilmu Pendidikan, Universitas Ahmad Dahlan \\ Jalan Ki Ageng Pemanahan No 19 Sorosutan, Umbulharjo, Yogyakarta 55162 \\ *Corresponding Author. e-mail: vera.erviana@pgsd.uad.ac.id
}

\begin{abstract}
Abstrak
Rusaknya moral bangsa dapat diamati dari memudarnya perilaku peserta didik yang dicermati dari cara berperilaku, bertutur kata yang kurang sopan dan tidak beretika. Penelitian ini bertujuan untuk mendeskripsikan penanganan dekadensi moral melalui penerapan pendidikan karakter cinta damai dan nasionalisme di SD Muhammadiyah Karangtengah. Penelitian ini termasuk jenis penelitian kualitatif deskriptif. Subjek dalam penelitian adalah kepala sekolah, guru kelas, guru PJOK, guru PAI, serta peserta didik. Pengumpulan data dilakukan dengan teknik pengamatan, wawancara, dan dokumentasi. Hasil analisis mengindikasikan bahwa dalam mengurangi kemrosotan moral peserta didik di usia sekolah dasar, pihak sekolah menanamkan pendidikan karakter cinta damai dan nasionalisme melalui pembiasaan, integrasi dalam pembelajaran, serta melalui budaya sekolah. Dalam penerapan pendidikan karakter tidak hanya usaha dari pihak sekolah saja, namun juga diperlukan adanya kerjasama antar semua elemen, mulai dari elemen pendidikan, keluarga, maupun lingkungan masyarakat. Hal itu merupakan langkah-langkah dalam mengurangi bahkan mencegah perilaku-perilaku kemrosotan moral yang terjadi di usia sekolah dasar.
\end{abstract}

Kata Kunci: dekadensi moral, pendidikan karakter, cinta damai, nasionalisme

\section{Handling Moral Decadence Through the Application of Peace Love Characters and Nationalism}

\begin{abstract}
The damage to the nation's morals can be observed from the waning behavior of students who are observed from how to behave, speak impolite and unethical words. This study aims to describe the handling of moral decadence through the application of peace-loving character education and nationalism in Muhammadiyah Elementary School, Karangtengah. This research is descriptive qualitative research. The subjects in this study were school principals, classroom teachers, PJOK teachers, Islamic education teachers, and students. The data was collected using observation, interview, and documentation techniques. The results of the analysis indicate that in reducing the moral decline in elementary school age, schools instill peace-loving character education and nationalism through habituation, integration in learning, and through school culture. In implementing character education, it is not only an effort from the school, but also requires cooperation between all elements, starting from the elements of education, family, and the community. This is a step in reducing and even preventing moral degeneration behavior that occurs at elementary school age.
\end{abstract}

Keywords: moral decadence, character education, peace-loving, nationalism

How to Cite: Erviana, V. Y. (2021). Penanganan dekadensi moral melalui penerapan karakter cinta damai dan nasionalisme . Jurnal Penelitian Ilmu Pendidikan, 14(1), 1-9. doi: https://doi.org/10.21831/jpipfip.v14i1.27149. Received 17-09-2019; Received in revised from 22-10-2019; Accepted 01-02-2021

This is an open-access article under the CC-BY-SA license. 


\section{PENDAHULUAN}

Pendidikan adalah sarana agar manusia dapat terus berkembang sesuai dengan zamannya. Pendidikan adalah upaya untuk mendewasakan seseorang dalam beberapa segi (Bahri, 2015). Pendidikan memiliki dampak yang lebih berarti bagi manusia. Pengetahuan yang didapat seseorang melalui pendidikan akan sangat berguna ketika masuk ke dalam dunia kerja (Maulidah \& Soejoto, 2017). Pendidikan saat ini identik dengan perkembangan ilmu pengetahuan dengan kemajuan dan teknologi yang sangat pesat pula. Tidak bisa dipungkiri bahwa dampak dari ilmu pengetahuan dan teknologi pada abad 4.0 berpengaruh besar bagi umat manusia dan para generasi penerus, baik itu pengaruh positif ataupun pengaruh negatif (Budiarto, 2020). Pengaruh positif diantaranya kemudahan jangkauan melalui internet serta kemudahan berkomunikasi dengan adanya berbagai aplikasi media sosial. Sedangkan pengaruh negatifnya di antaranya penyaringan informasi negatif yang didapatkan dari kemudahan mengakses apapun di internet. Selain itu dengan perkembangan IPTEK yang semakin kompleks mengakibatkan masyarakat saat ini kurang dalam bersosialisasi dengan lingkungannya, budaya barat lebih diterima, bahkan budaya barat beradaptasi di dalam para generasi penerus, sampai pada era saat ini para generasi penerus, kehilangan jati dirinya sebagai bangsa Indonesia, sehingga perilaku tersebut mengakibatkan kemunduran akhlak atau moral yang biasa disebut dekadensi moral. Krisis moral di kalangan generasi muda di seluruh pelosok tanah air merupakan salah satu indikator terbesar dari fenomena tersebut, diantaranya kegagalan pada pendidikan di bidang pendidikan formal, informal dan nonformal (Iskarim, 2017).

Dekadensi moralitas, atau yang sering disebut degradasi moral, saat ini tidak hanya merugikan orang dewasa, tetapi juga berdampak pada peserta didik yang akan menjadi keturunan bangsa Indonesia di masa depan. Para orang tua, pendidik dan semua pihak yang terlibat dalam pendidikan, agama dan bidang sosial mengeluhkan bahwa beberapa perilaku peserta didik yang melebihi norma, kesopanan dan kesusilaan, perkelahian, perundungan, ketergantungan dengan gadget dan lain sebagainya. Dekadensi moralitas di kalangan generasi muda di Indonesia merupakan masalah yang erat kaitannya dengan tingkat moral sosial, dalam dunia pendidikan, khususnya dunia pendidikan dasar, merupakan salah satu indikasi penyebab terjadinya pencurian, perundungan, dan masalah lainnya (Cahyo, 2017).

Bentuk penyimpangan yang terjadi bukan tanpa bukti bahwa kemajuan ilmu pengetahuan dan teknologi juga membawa konsekuensi logis dalam menciptakan situasi yang menggambarkan degradasi moral dengan istilah dekadensi moral (Daulay, 2016). Oleh karena itu, Siregar menyatakan perlunya penguatan pendidikan karakter mulai dari SD, SMP, SMA hingga Perguruan Tinggi, dari semua jenjang pendidikan (Kurniawan, 2016). Karakter merupakan cara hidup yang menggarisbawahi perbedaan antara manusia dan hewan. Pendidikan karakter berperan penting bagi peserta didik yang menjadi sebuah tuntutan untuk tidak perlu dipersoalkan, dalam pelaksanaannya belum ada standar dan aturan mutlak tentang upaya menyelenggarakan pendidikan karakter (Murniyetti, Engkizar \& Anwar, 2016).

Berdasarkan observasi pada bulan Agustus 2018 di SD Muhammadiyah Karangtengah, beberapa permasalahan yang terjadi, yakni perilaku tindakan kekerasan antar peserta didik, permasalahan kenakalan peserta didik, dan banyaknya peserta didik yang mengganggu temanya (bullying). Selain itu, banyaknya peserta didik yang berbicara dan berperilaku yang menyimpang dari aturan atau norma. Begitu memprihatinkan kondisi karakter calon generasi bangsa saat ini, mudah tersulut emosi, rendahnya rasa saling menghormati dan menghargai, serta rendahnya rasa simpati dan empati antar peserta didik sehingga meninggalkan norma-norma yang seharusnya dilestarikan dan dibudayakan. Selain permasalahan menyimpang yang telah dipaparkan, terdapat permasalahan lagi di mana peserta didik sudah mulai terkontaminasi dengan budaya barat. Mereka lebih menyukai lagu-lagu barat daripada lagu tentang nasionalisme. Selain itu, lunturnya rasa cinta tanah air ditandai dengan tidak seriusnya saat melaksanakan upacara bendera setiap hari Senin di sekolah, penggunaan produk luar negeri lebih membanggakan daripada penggunaan produk buatan Indonesia, dan memiliki tingkat pemahaman yang lebih rendah dalam menggunakan bahasa Indonesia yang berkualitas.

Pendidikan karakter sangat dibutuhkan di zaman sekarang untuk membentuk generasi penerus bangsa yang berkualitas unggul dengan menumbuhkan rasa sikap yang bertanggung jawab 
dalam menghadapi era globalisasi (Safitri, 2020). Karakter yang perlu diintegrasikan dalam pembelajaran diantaranya karakter cinta damai dan nasionalisme. Karakter cinta damai merupakan perilaku yang membuat setiap orang merasakan ketenangan dan keamanan yang muncul dalam dirinya melalui kepribadian yang cinta damai di kalangan peserta didik, sehingga dapat terhindar dari berbagai bentuk gangguan yang memicu pertengkaran dan perudungan (Halim \& Mislinawati, 2019). Bagi peserta didik karakter cinta damai dapat diwujudkan dengan menghindari konflik, tidak melakukan kekerasan, dan mengedepankan keharmonisan, sikap toleransi, saling menghormati dan hubungan yang sejajar pada setiap individu dan kelompoknya (Syaefudin \& Santoso, 2018). Lingkungan di sekolah dasar merupakan dasar pijakan dalam menumbuhkan norma, kepercayaan dan kebiasaan untuk membentuk karakter nasionalisme yang kuat untuk menjadi pribadi dalam menghadapi kehidupan di masa mendatang yang dinamis dan beragam (Rusiyono \& Apriani, 2020). Perilaku nasionalisme sebagai bagian dari nilai-nilai budi pekerti yang wajib dimiliki setiap individu, khususnya peserta didik, hal ini menjadikan proses pembangunan menjadi aset penting bagi kelangsungan hidup berbangsa dan bernegara (Meldawati \& Ersi, 2020).

Untuk mewujudkan karakter yang berbudi serta memiliki karakter cinta damai dan nasionalisme diperlukan berbagai upaya, baik dari pihak keluarga maupun pihak sekolah. Upaya pertama yang dapat dilakukan di lingkungan keluarga dalam mewujudkan karakter cinta damai dan nasionalisme diantaranya, membiasakan anak untuk menghargai setiap perbedaan pendapat di lingkungan keluarga serta menanamkan sikap cinta tanah air sedini mungkin dengan membeli produk-produk dalam negeri. Usaha yang mampu dijadikan sebagai alternatif dapat dilakukan di lingkungan sekolah adalah dengan mengintegrasikan proses pembelajaran secara tematik atau terpadu sehingga pembelajaran lebih komprehensif. Selain itu, penanaman karakter berbasis budaya sekolah, yakni dengan pembiasaan nilai-nilai dalam keseharian sekolah, dan penanaman karakter berbasis masyarakat (Kemendikbud, 2010). Melalui berbagai upaya tersebut diharapkan mampu menciptakan generasi bangsa yang memiliki perilaku yang berbudi dan berkarakter mulia sehingga tidak ada lagi kasus-kasus yang berkaitan dengan moral pelajar terutama dalam lingkungan pendidikan sekolah dasar.

Penelitian ini mengambil tempat di SD Muhammdiyah Karangtengah. Analisis dilakukan terkait dengan upaya tentang penanganan dekadensi moral melalui penerapan karakter cinta damai dan nasionalisme di SD Muhammadiyah Karangtengah. Sebagaimana hal tersebut difokuskan dalam penanaman karakter cinta damai dan nasionalisme dengan berbagai upaya-upaya untuk mengurangi perilaku dekadensi moral di lingkungan pendidikan sekolah dasar.

\section{METODE}

Jenis penelitian yang digunakan adalah penelitian deskriptif kualitatif. Penelitian ini dilaksanakan di SD Muhammadiyah Karangtengah yang beralamatkan di Pucong Growong, Karangtengah, Imogiri, Bantul, Daerah Istimewa Yogyakarta. Waktu penelitian berlangsung pada bulan April 2019. Subjek penelitian meliputi kepala sekolah, guru kelas, guru PAI, guru PJOK, dan beberapa peserta didik. Objek dalam penelitian ini adalah kegiatan yang dilakukan sebagai program penanaman karakter cinta damai dan nasionalisme sebagai upaya untuk mengurangi perilaku dekadensi moral di lingkungan SD Muhammadiyah Karangtengah. Teknik pengumpulan data dengan menggunakan observasi, wawancara, dan dokumentasi. Data kemudian dianalisis dengan menggunakan model Miles and Huberman yang terdiri dari reduksi data, penyajian data, dan penarikan kesimpulan. Sedangkan keabsahan data dilakukan dengan triangulasi sumber dan triangulasi teknik.

\section{Hasil}

\section{HASIL DAN PEMBAHASAN}

Hasil penelitian yang dilakukan menjabarkan berbagai upaya-upaya tentang penanganan dekadensi moral melalui penerapan karakter cinta damai dan nasionalisme di SD Muhammadiyah Karangtengah. Adapun, hasil tersebut dijabarkan ke dalam aspek pembiasaan, integrasi dalam pembelajaran, dan budaya sekolah yang akan diuraikan sebagai berikut. 


\section{Pembiasaan}

Penerapan pendidikan karakter cinta damai dan nasionalisme di SD Muhammadiyah Karangtengah guna mengurangi perilaku dekadensi moral dimulai dari pembiasaan. Pembiasaan yang terjadi di lingkungan pendidikan seperti sekolah dengan upaya kegiatan rutin sekolah, kegiatan spontan yang terjadi, dan sikap teladan, pengkondisian, dan tata tertib. Karakter cinta damai dan nasionalisme ditanamkan dengan pembiasaan kegiatan rutin diantaranya membiasakan untuk jabat tangan dan menerapkan 5S (Senyum, Salam, Sapa, Sopan, dan Santun) bagi seluruh warga sekolah, adapun setiap pagi dilakukan berbaris sebelum memasuki kelas, upacara yang rutin setiap hari senin dan perayaan hari pahlawan, serta rajin mengikuti perlombaan.

Pada kegiatan spontan juga ditanamkan karakter cinta damai dan nasionalisme di antaranya menjenguk teman yang sakit dan membantu orang lain ketika terkena musibah atau bencana serta sikap peserta didik untuk saling menegur dalam perbuatan kebaikan. Melalui kegiatan rutin dan spontan merupakan upaya sekolah dalam mewujudkan penerapan pendidikan karakter. Karakter cinta damai dan nasionalisme ditegakkan dalam kepribadian peserta didik dengan pembiasaan yang dilakukan setiap harinya di sekolah. Keterlibatan pihak sekolah mulai dari kepala sekolah, pendidik, serta warga sekolah memberikan dukungan dalam terciptanya karakter tersebut.

Pembiasaan berupa keteladanan juga diberikan oleh guru dan karyawan di SD Muhammadiyah Karangtengah dengan memberikan contoh berperilaku sopan dan santun, budaya hidup bersih, dan memberikan pengetahuan tentang ilmu agama. Pengetahuan tentang ilmu agama sangat penting guna menanamkan pondasi yang kokoh, seperti membiasakan membaca al-quran, shalat berjamaah, berdo'a sebelum dan sesudah pembelajaran. Pembiasaan melalui keteladanan merupakan strategi efektif dalam membentuk perilaku peserta didik yang bermoral. Banyak peserta didik yang melakukan penyimpangan norma karena melihat atau meniru perbuatan orang dewasa yang negatif sehingga ia meniru perbuatan negatif tersebut. Oleh sebab itu diperlukan keteladanan atau contoh yang baik agar ketika peserta didik meniru, itu meniru perbuatan yang baik pula.

Kemudian pembiasaan melalui pengkondisian memiliki kontribusi yang penting guna menerapkan pendidikan karakter cinta damai dan nasionalisme. Di SD Muhammadiyah Karangtegah pengkondisian lingkungan sekolah dan kelas cukup nyaman, tenang, serta damai. Berdasarkan hasil pengamatan, di lingkungan sekolah terdapat beberapa poster atau kata-kata bijak yang berhubungan dengan pendidikan karakter tentang pentingnya berperilaku yang baik atau bermoral. Hal itu dengan tujuan agar peserta didik memiliki moral yang baik dan berintegritas. Suasana belajar yang damai, kekerabatan yang rukun, serta saling menebar kasih sayang dapat memupuk karakter saling mencintai antar sesama, memiliki jiwa toleran dalam hormat menghormati dan penghargaan atas segala perbedaan yang ada. Selain itu wujud dari pengkondisian guna menerapkan pendidikan karakter nasionalisme berupa foto presiden dan wakil presiden yang ada di dalam kelas, foto para pahlawan dan tokoh nasional, bendera merah putih, foto lambang negara dan teks sumpah pemuda. Selain itu, melakukan pembiasaan dengan menaati peraturan atau tata tertib sekolah merupakan hal yang sangat penting dalam menerapkan pendidikan karakter. SD Muhammadiyah Karangtengah memiliki tata tertib yang dipajang di dinding sekolah. Dengan adanya tata tertib maka warga sekolah akan berupaya untuk bertindak dan bersikap selaras pada aturan dan norma yang dipegang. Ketika ada yang melanggar peraturan yang telah dibuat maka akan mendapatkan sanksi. Hal ini dilakukan guna mendidik warga sekolah dan peserta didik SD Muhammadiyah Karangtengah untuk berusaha menaati aturan dan berperilaku dengan baik yang tidak melanggar norma.

\section{Integrasi di dalam Pembelajaran}

Pembelajaran merupakan perantara dalam menerapkan pendidikan karakter terutama pendidikan karakter cinta damai dan nasionalisme. Dalam proses pembelajaran, siswa tidak hanya belajar ilmu pengetahuan, tetapi juga belajar bagaimana melakukan sesuatu dan berperilaku pada diri sendiri dan orang lain/kelompok. Hal ini dilakukan guna menerapkan pendidikan-pendidikan moral bagi peserta didik. Berdasarkan hasil penelitian menunjukkan bahwa integrasi pembelajaran di kelas III A dan II C di SD Muhammadiyah Karangtengah dapat mengajarkan peserta didik untuk memiliki karakter cinta damai dan nasionalisme sehingga membekali peserta didik untuk bersikap baik dan bermoral. Pembelajaran yang diselenggarakan dengan Kurikulum 2013 menunjang dalam penanaman 
karakter. Kurikulum 2013 mengandung kompetensi inti yaitu kompetensi sikap religius (K1) \& kompetensi sikap sosial (K2). Melalui kompetensi inti yang harus dikuasai siswa memberikan peluang bagi pendidik untuk mengintegrasikan penanaman karakter cinta damai dan nasionalisme pada pembelajaran.

Pembelajaran yang diselenggarakan dapat diintegrasikan karakter cinta damai dengan ditunjukkan menciptakan suasana kelas nyaman, damai, saling menyayangi, kerukunan tetap terjaga serta membudayakan berperilaku anti kekerasan sehingga menciptakan karakter yang mulia dan bermoral. Materi pembelajaran yang disampaikan kepada siswa dengan mengkaitkan pada kehidupan sehari-hari sehingga siswa dapat mempelajari sikap dan perilaku yang baik dari hal yang didapatkan dalam pembelajaran tersebut.

Karakter nasionalisme berdasarkan hasil penelitian ditunjukkan dengan menyanyikan lagulagu nasional ketika sebelum pembelajaran, saat pembelajaran, maupun setelah pembelajaran. Kemudian dengan penerapan berbahasa Indonesia yang baik dan benar pada peserta didik. Selain itu dengan dipajangnya bingkai foto/gambar kepresidenan dan wakil presiden, bendera merah putih, lukisan para pahlawan kemerdekaan, serta teks sumpah pemuda. Peserta didik diminta untuk menghafalkan teks pancasila dan sumpah pemuda dengan tujuan supaya memiliki sikap dan perilaku ideologi Pancasila bagi peserta didik.

\section{Budaya Sekolah}

Program penguatan pendidikan karakter cinta damai dan nasionalisme dapat diterapkan melalui budaya sekolah. Budaya sekolah merupakan kebiasaan-kebiasaan yang dilakukan oleh pihak sekolah secara rutin dan konsisten. Budaya sekolah yang tercipta diantaranya menyelenggarakan upacara bendera di lingkungan sekolah pada hari Senin, melaksanakan peringatan hari besar nasional (PHBI), serta membudayakan jabat tangan dan 5S (Senyum, Salam, Sapa, Sopan, dan Santun) selama di sekolah. Dalam kegiatan upacara setiap hari Senin peserta didik diajarkan dan ditanamkan untuk memiliki karakter yang berjiwa nasionalisme. Peringatan Hari Besar Nasional (PHBI) juga rutin dilaksanakan dalam rangka mengajarkan peserta didik akan pentingnya memperingati dan mengenang perjuangan pahlawan dan nantinya akan tumbuh rasa cinta tanah air dan jiwa nasionalisme. Peringatan Hari Besar Nasional yang biasa dilakukan oleh SD Muhammadiyah seperti upacara dalam memperingati hari kemerdekaan, peringatan Hari Kartini, serta peringan hari pendidikan nasional. Sedangkan untuk karakter cinta damai diterapkan ketika jabat tangan dan 5S (senyum, sapa, salam, sopan, santun). Ketika jabat tangan akan terjadinya interaksi yang baik antar guru dan peserta didik. Selain itu, jabat tangan mengajarkan anak untuk berperilaku sopan, santun, serta menghargai orang yang lebih tua.

Budaya sekolah yang telah tercipta di SD Negeri Karantengah ini mampu membentuk peserta didik untuk menjadi pribadi yang bermoral. Karakter cinta damai dan nasionalisme yang secara terintegrasi dari berbagai bentuk budaya di sekolah mampu tertanam pada diri peserta didik. Budaya sekolah perlu dipertahankan dan dikembangkan lagi ke dalam aktivitas yang melibatkan peserta didik.

\section{Hambatan Penanaman Karakter Cinta Damai dan Nasionalisme}

Berdasarkan hasil penelitian menunjukkan bahwa adanya hambatan yang dialami oleh SD Muhammadiyah Karangtengah diantaranya adalah kondisi latar belakang peserta didik yang berbedabeda membuat sekolah cukup kesulitan dalam menerapkan pendidikan karakter cinta damai dan nasionalisme yang berhubungan dengan perilaku atau moral peserta didik. Lingkungan masyarakat sekitar dan lingkungan tempat tinggal peserta didik mempengaruhi dalam penanaman karakter cinta damai dan nasionalisme. Adapun hambatan juga berasal dari pihak keluarga, kesibukan orang tua yang berkerja tidak memperhatikan tumbuh kembang anaknya dengan baik.

Berdasarkan dari hasil analisis yang dipaparkan, dalam mengurangi kemrosotan moral di usia sekolah dasar pihak sekolah SD Muhammadiyah Karangtengah menanamkan pendidikan karakter cinta damai dan nasionalisme melalui beberapa upaya. Adapun upaya tersebut melalui pembiasaan, integrasi dalam pembelajaran, serta melalui budaya sekolah. Meskipun dalam upaya tersebut masih terdapat beberapa hambatan dari segi latar belakang peserta didik, orang tua, dan lingkungan masyarakat diperlukan kerjasama dengan pihak sekolah. Adanya kerjasama antar semua elemen, mulai dari elemen pendidikan, keluarga, maupun lingkungan masyarakat. Hal itu merupakan langkah- 


\section{Jurnal Penelitian Ilmu Pendidikan, 14 (1), 2021 - 6}

Erviana

langkah dalam mengurangi bahkan mencegah perilaku-perilaku kemrosotan moral yang terjadi di usia sekolah dasar. Pendidikan karakter cinta damai dan nasionalisme ditanamkan melalui pembiasaanpembiasaan yang diterapkan oleh pihak sekolah. Pembiasaan peserta didik dalam hal-hal yang positif serta didukung dengan kegiatan yang ada di sekolah diharapkan mampu membekali peserta didik moral yang bagus dan beretika sehingga tidak ada lagi perilaku-perilaku dekadensi moral yang terjadi di kalangan peserta didik sekolah dasar.

\section{Pembahasan}

Program penguatan pendidikan karakter saat ini sebagai program dari pemerintah yang dicanangkan guna memperbaiki moral para penerus bangsa. Mengingat banyak sekali peristiwaperistiwa yang berkaitan dengan kemrosotan moral terutama di usia sekolah dasar. Penanaman pendidikan karakter alangkah baiknya diterapkan sedini mungkin agar mampu menghadapi tantangan yang semakin global di masa mendatang. Melalui penerapan pendidikan karakter nantinya akan menciptakan generasi yang berkualitas, tidak hanya cerdas dalam hal kognitif namun juga memiliki moral atau akhlak yang baik. Pendidikan karakter sebenarnya adalah pendidikan yang tidak hanya bertumpu pada dan melemahkan kecerdasan, tetapi juga bertumpu pada nilai-nilai kemanusiaan dan kebangsaan dengan Pancasila sebagai ideologi bangsa, dan membentuk karakter warga negara (Mulia \& Aini, 2013). Membangun karakter di dalam lingkungan sekolah merupakan sebuah upaya dalam berakhlak dan bermoral selama proses pembelajaran yang ada di sekolah (Prihatmojo \& Badawi, 2020). Karakter cinta damai dan nasionalisme perlu ditanamkan pada diri peserta didik sejak dini. Hal ini akan menciptakan pribadi manusia yang senantiasa bermoral untuk menjaga kedamaian dan berjiwa kebangsaan.

Sikap cinta damai memang diperlukan, karena dapat digunakan untuk memberikan nilai individu kepada siswa di sekolah untuk membina siswa yang berkepribadian baik, berpengetahuan dan bertekad untuk belajar lebih baik, melampaui nilai-nilai dirinya sendiri dan lebih menghargai orang lain (Hikmah \& Amriyati, 2017). Pada saat yang sama karakter nasionalis dapat membangun masa depan yang cerah bagi Indonesia, karena tanpa karakter nasionalis bangsa Indonesia tidak akan memiliki masa depan yang cerah (Widiatmaka, 2016). Penerapan pendidikan karakter nasionalisme bertujuan guna mengurangi penurunan moral di zaman yang serba maju pada saat ini (Rischa, Abdul, \& Winarno, 2019). Penanaman pendidikan karakter cinta damai dan nasionalisme bagi peserta didik di sekolah membentuk peserta didik yang bermoral. Sehingga dekadensi moral yang dapat menyerang peserta didik sejak dini mampu untuk dicegah dan diatasi dengan pendidikan karakter cinta damai dan nasionalisme. Strategi dalam pembangunan karakter di dalam diri peserta didik adalah dengan mengintervensi, mencontoh, membiasakan, mempromosikan, memperkuat, dan berpartisipasi dalam pihak lain (Mislia, Mahmud \& Manda, 2016). Terdapat berbagai upaya dari pihak sekolah dalam menangani dekadensi moral dengan penanaman karakter tersebut. Melalui upaya pembiasaan, kegiatan rutin, kegiatan spontan, keteladanan, pengkondisian, dan tata tertib.

Upaya penanaman karakter cinta damai dan nasionalisme untuk penanganan dekadensi moral dilakukan melalui pembiasaan yang ada di SD Muhammadiyah Karangtengah. Pembiasaan menurut Mulyasa (Shoimah, Sulthoni, \& Soepriyanto, 2018) adalah sebuah hal yang secara terus menerus dilakukan hingga menjadi sebuah rutinitas dan pembiasaan diri. Penerapan pendidikan karakter dapat melalui pembiasaan sekolah yang menerapkan beberapa kegiatan (Shoimah, Sulthoni, \& Soepriyanto, 2018). Pembiasaan yang baik dapat muncul jika sekolah menerapkan disiplin dan komitmen positif untuk menyelenggarakan pendidikan karakter sesuai dengan kearifan lokal dan budaya lokal (Hermino \& Arifin, 2020). Apabila kegiatan ini diulangi secara rutin hingga menjadi sebuah kebiasaan maka akan terbentuk karakter seseorang, dan pada akhirnya kebiasaan tersebut tidak hanya menjadi sebuah rutinitas saja, tetapi juga menjadi sebuah karakter (Annisa, Wiliah, \& Rahmawati, 2020). Pembiasaan yang dilakukan di sekolah menjadi peluang untuk dapat mengintegrasikan karakter cinta damai dan nasionalisme. Sehingga diperlukan dukungan yang kuat terkait dengan pembiasaan yang dilakukan di sekolah dari seluruh warga sekolah yang ada.

Kegiatan rutin dan kegiatan spontan yang terdapat di sekolah juga menjadi upaya dalam menanamkan pendidikan karakter cinta damai dan nasionalisme. Peserta didik selain belajar juga dapat untuk diberikan kegiatan-kegiatan yang mendorong kepribadiannya dalam membangun karakter 
diri. Adanya aktivitas sehari-hari yang dilakukan oleh sekolah dan aktivitas sehari-hari yang diusahakan oleh sekolah dapat menegakkan nilai-nilai karakter pada diri peserta didik (Supraptiningrum \& Agustini, 2015). Kegiatan-kegiatan yang dilakukan membutuhkan dukungan dari warga sekolah, sehingga tercipta lingkungan sekolah yang positif untuk dapat diteladani oleh peserta didik. Pada upaya keteladanan yang dilakukan oleh pihak sekolah memberikan dampak positif kepada peserta didik untuk membentuk karakter yang positif. Tidak hanya pihak sekolah saja yang memberikan keteladanan, namun juga dari pihak keluarga atau orangtua. Pola asuh orang tua berhubungan dengan dekadensi moral dikalangan remaja (Ningrum, 2015).

SD Muhammadiyah Karangtengah mengintegrasikan pendidikan karakter selain melalui pembiasaan, kegiatan rutin, kegiatan spotan, dan keteladanan juga melalui pembelajaran di kelas. Pendidik menanamkan karakter cinta damai dan nasionalisme melalui pembelajaran yang dilakukan. Aktivitas-aktivitas yang direncanakan oleh pendidik terintegrasi penanaman karakter cinta damai dan nasionalisme. Integrasi isi/konten pendidikan karakter yang sudah mapan ke dalam semua disiplin ilmu (Rosad, 2019). Melalui pengenalan nilai, promosi pemahaman tentang pentingnya nilai dan internalisasi nilai ke dalam perilaku sehari-hari siswa melalui proses pembelajaran, dilaksanakan pendidikan karakter komprehensif dalam pembelajaran, baik di dalam kelas dan di luar kelas (Ansori, 2020). Perumusan dalam sebuah tujuan pendidikan karakter adalah sebagai upaya peningkatan mutu dan hasil pendidikan, sehingga terwujud pembentukan karakter dan akhlak yang tinggi (Zuriah, 2015). Pihak-pihak yang mempengaruhi pendidikan harus bekerja sama untuk menyukseskan program pendidikan karakter (Faridi, 2014). Meskipun ditemukan hambatan dari orang tua dalam penanaman karakter pada peserta didik, namun orang tua juga ikut serta mengembangkan karakter karena orang tua yang menjadi guru akhlak pertama bagi anak-anak (Daniati, 2019). Orang tua, pendidik, dan individu tertentu lainnya menjadi pemain peran penting dalam hal pengembangan karakter dan pembangunan karakter (Freeks, 2015).

\section{PENUTUP}

Penanganan dekadensi moral melalui penanaman karakter cinta damai dan nasionalisme di SD Muhammadiyah Karangtengah dilihat dari tiga aspek yaitu pembiasaan, integrasi dalam pembelajaran, dan budaya sekolah. Pembiasaan yang rutin ada dan muncul di sekolah dalam menerapkan pendidikan karakter cinta damai dan nasionalisme seperti dalam kegiatan rutin, kegiatan spontan, keteladanan, pengondisian, serta melalui tata tertib. Pembiasaan-pembiasaan tersebut diantaranya melaksanakan sapa dan jabat tangan setiap pagi dan sebelum pulang sekolah, berbaris sebelum memasuki kelas, menjenguk teman yang sakit, membantu korban bencana, membiasakan budaya bersih, mengikuti berbagai perlombaan, melaksanakan tahfidz qur'an, serta melaksanakan tata tertib sekolah. Penerapan pendidikan karakter dapat dilakukan melalui integrasi pada pembelajaran selama di lingkungan sekolah dengan membangun karakter cinta damai dan nasionalisme. Peserta didik diajarkan tidak hanya dalam ilmu pengetahuan saja namun juga cara bersikap dan berperilaku. Penerapan pendidikan karakter cinta damai dan nasionalisme yang diterapkan di SD Muhammadiyah Karangtengah dilakukan melalui budaya sekolah. Budaya yang rutin dilaksanakan oleh SD Muhammadiyah Karangtengah seperti pelaksanaan upacara yang diselenggarakan oleh sekolah, memperingati hari besar nasional (PHBI), serta melalui jabat tangan dan 5S setiap pagi dan sebelum pulang sekolah. Berbagai langkah-langkah dan upaya yang dilakukan pihak sekolah guna mengurangi kemrosotan moral melalui penerapan pendidikan karakter cinta damai dan nasionalisme tentunya bertujuan agar kedepannya peserta didik memiliki perilaku dan akhlak yang berbudi mulia. Meskipun terdapat hambatan yang dialami sekolah dalam menerapkan pendidikan karakter cinta damai dan nasionalisme. Hambatan dalam menerapkan pendidikan karakter berasal dari lingkungan keluarga, dan lingkungan masyarakat. Tidak singkronnya pendidikan karakter yang ada di sekolah dan di rumah atau lingkungan masyarakat membuat sekolah kesulitan menerapkan pendidikan karakter. Meskipun demikian, hasil penelitian ini merekomendasikan bagi sekolah untuk memberikan prioritas utama dalam penanganan dekadensi moral melalui penerapan karakter. Adapun tindak lanjut perlu adanya penelitian lebih lanjut terkait dengan penanaman karakter yang lain seperti jujur, tanggung jawab dalam upaya menangani dekadensi moral di siswa sekolah dasar. 


\section{Jurnal Penelitian Ilmu Pendidikan, 14 (1), 2021 - 8 \\ Erviana}

\section{UCAPAN TERIMA KASIH}

Peneliti ingin menyampaikan terima kasih kepada kepala sekolah, guru kelas, guru PAI, guru PJOK, dan peserta didik di SD Muhammadiyah Karangtengah yang beralamatkan di Pucong Growong, Karangtengah, Imogiri, Bantul, Daerah Istimewa Yogyakarta.

\section{DAFTAR PUSTAKA}

Annisa, M. N., Wiliah, A., \& Rahmawati, N. (2020). Pentingnya pendidikan karakter pada anak sekolah dasar di zaman serba digital. BINTANG, 2(1), 35-48.

Ansori, Y. Z. (2020). Pembinaan karakter siswa melalui pembelajaran terpadu di sekolah dasar. Jurnal Educatio FKIP UNMA, 6(1), 177-186.

Bahri, S. (2015). Implementasi pendidikan karakter dalam mengatasi krisis moral di sekolah. Jurnal Pendidikan Islam Ta'allum, 3(1), 57.

Budiarto, G. (2020). Indonesia dalam pusaran globalisasi dan pengaruhnya terhadap krisis moral dan karakter. Jurnal Pamator: Jurnal Ilmiah Universitas Trunojoyo, 13(1), 50-56.

Cahyo, E. D. (2017). Pendidikan karakter guna menanggulangi dekadensi moral yang terjadi pada peserta didik sekolah dasar. EduHumaniora, Jurnal Pendidikan Dasar Kampus Cibiru, 9(1), $16-26$.

Daulay. (2016). Dekadensi moral di kalangan pelajar (revitalisasi strategi pai dalam menumbuhkan moralitas bangsa). Edukasi Islamika, 1(1).

Daniati, S. P. (2019). Natural school culture as a free and fun alternative education in building the students' character. Elementary Education Online, 18(1).

Faridi, A. (2014). The difficulties of english teachers in instilling character building through narrative stories at elementary schools in Central Java, Indonesia. International Journal of Contemporary Applied Sciences, 1(2), 68-82.

Freeks, F. E. (2015). The influence of role-players on the character-development and characterbuilding of South African college students. South African Journal of Education, 35(3) 1-13.

Halim, A. R., \& Mislinawati, M. (2019). Upaya guru dalam menerapkan karakter cinta damai pada siswa sekolah dasar negeri 51 Kota Banda Aceh. Jurnal Ilmiah Mahasiswa Pendidikan Guru Sekolah Dasar, 4(2), 1-10.

Hermino, A., \& Arifin, I. (2020). Contextual character education for students in the senior high school. European Journal of Educational Research, 9(3), 1009-1023.

Hikmah, A. N., \& Amriyati, U. (2017). Analisis hubungan hasil belajar dengan karakter cinta damai di smpn 02 Muaro Jambi. Jurnal Pendidikan Matematika dan Sains, 4(1), 1-6.

Iskarim, M. (2017). Dekadensi moral di kalangan pelajar (revitalisasi strategi PAI dalam menumbuhkan moralitas generasi bangsa). Edukasia Islamika, 1(1), 1-20.

Kemendikbud. (2010). Bahan pelatihan: Pengembangan pendidikan budaya dan karakter bangsa. Jakarta: Kemdiknas.

Kurniawan, S. (2016). Pendidikan karakter: Konsepsi dan implementasinya secara terpadu di lingkungan keluarga, sekolah, program perguruan tinggi. Yogyakarta: Ar-Ruzz Media.

Maulidah, F., \& Soejoto, A. (2017). Pengaruh tingkat pendidikan, pendapatan dan konsumsi terhadap jumlah penduduk miskin di provinsi Jawa Timur. Jurnal Ekonomi Pendidikan Dan Kewirausahaan, 3(2), 227-240.

Meldawati, M., \& Ersi, L. (2020). Gambaran pendidikan karakter oleh guru sejarah dalam menanamkan nasionalisme peserta didik. Jurnal Pendidikan Tambusai, 4(2), 1299-1308.

Mislia, M., Mahmud, A., \& Manda, D. (2016). The implementation of character education through scout activities. International Education Studies, 9(6), 130.

Mulia, M. S., \& Aini, D. I. (2013). Karakter manusia bangsa. Bandung: Nuansa Cendekia.

Murniyetti, M., Engkizar, E., \& Anwar, F. (2016). Pola pelaksanaan pendidikan karakter terhadap siswa sekolah dasar. Jurnal Pendidikan Karakter, 6(2), 156-166.

Ningrum, D. (2015). Kemrosotan moral di kalangan remaja: Sebuah penelitian mengenai parenting styles dan pengajaran adab. UNISA, XXXVII No.82s 


\section{Jurnal Penelitian Ilmu Pendidikan, 14 (1), 2021 - 9 \\ Erviana}

Prihatmojo, A., \& Badawi, B. (2020). Pendidikan karakter di sekolah dasar mencegah degradasi moral di era 4.0. DWIJA CENDEKIA: Jurnal Riset Pedagogik, 4(1), 142-152.

Rischa, F. N., Abdul, S., \& Winarno. (2019). The Implementation of nationalism in globalization era using value clarification learning models. Advance in social science: Education and Humanity Research, 287. DOI: https://doi.org/10.2991/icesre-18.2019.33.

Rosad, A. M. (2019). Implementasi pendidikan karakter melalui manajemen sekolah. Tarbawi: Jurnal Keilmuan Manajemen Pendidikan, 5(02), 173-190.

Rusiyono, R., \& Apriani, A. N. (2020). Pengaruh metode storytelling terhadap penanaman karakter nasionalisme pada siswa SD. LITERASI (Jurnal Ilmu Pendidikan), 11(1), 11-19.

Safitri, K. (2020). Pentingnya pendidikan karakter untuk siswa sekolah dasar dalam menghadapi era globalisasi. Jurnal Pendidikan Tambusai, 4(1), 264-271.

Shoimah, L., Sulthoni, \& Soepriyanto, Y. (2018). Pendidikan karakter melalui pembiasaan di sekolah dasar. JKTP, I(2). Diakses dari http://journal2.um.ac.id/index.php/jktp/article/download/4206/2774.

Supraptiningrum \& Agustini. (2015). Membangun karakter peserta didik melalui budaya sekolah. Jurnal Pendidikan Karakter, 5(2).

Syaefudin, S., \& Santoso, S. (2018). Tipologi kepemimpinan kepala sekolah dalam pembentukan karakter cinta damai siswa smp piri 1 Yogyakarta. MANAGERIA: Jurnal Manajemen Pendidikan Islam, 3(1), 47-67.

Widiatmaka, P. (2016). Pembangunan karakter nasionalisme peserta didik di sekolah berbasis agama Islam. JPK (Jurnal Pancasila dan Kewarganegaraan), 1(1), 25-33.

Zuriah, N. (2015). Pendidikan moral di budi pekerti dalam perspektif perubahan. Jakarta: PT. Bumi Aksara. 